\title{
Travelling Identities, Bodies and the Poetics of Difference: Travel Writing in Assamese Literature
}

\author{
Shibashish Purkayastha \\ PhD Research Scholar, Department of Humanities and Social Sciences, Indian Institute of \\ Technology, Guwahati. ORCID: oooo-0002-1630-0038. \\ Email: shibashish.purkayastha@gmail.com
}

\begin{abstract}
The purpose of this article shall be to trace a historical trajectory of the development of travel writing as a distinct genre in Assamese literature. In Assam, the germ of travel writing dates back to the nineteenth century in which European travellers wrote extensively on their visits to North East India, which were exotic accounts of their encounters with an alien culture. The first Assamese travelogue was Jnanadabhiram Barua's BilatarSithi which was serialized in the Assamese monthly Banhi in 1909 which, for the first time, narrativized a non-westerners account of his travels to the United Kingdom in a series of letters. However, the genre of travel writing in Assam seemed to attain its growth and maturity in the days following Independence. In the late 1980s, the travel writer, as a move away from merely offering descriptive sketches eulogizing their travels, started looking back into the nuances of the self as a site of imaginative and critical reflections. The onus of this article shall be to trace the growth and development of travel writing in Assamese literature and shall then move on to reviewing some of the important travel narratives of Assamese literature which seem to problematize our understandings of the nation, identity, body and the gaze. Additionally, it shall also examine whether these travel narratives attempt to expand the discursive and generic boundaries of the form of postcolonial travel writing. Through close readings of select travel narratives, I argue that they posit a poetics of difference by attempting to engage in a dialogue between their encounters with foreign cultures vis-à-vis, the nuances of everyday material realities of the life of the traveller.
\end{abstract}

Keywords: agency, travel, history, identity, body, empathy

\section{Introduction}

It would almost be a truism to state that postcolonial travel writing has been grappling with issues of globalization, cultural hybridization, and movements-of people and ideas. Carl Thompson in his essay on "Defining the Genre" in Travel Writing: A Critical Idiom rightly argues that, to travel is through make a movement through "space" (Thompson, 2011, p.9). Way back in 1929, the French writer Victor Segalen had first emphasized upon the centrality of the body in travel narratives, what he calls the 'Aesthetics of Diversity ${ }^{\text {i }}$ challenging the similar aesthetic appeal of the physical landscapes to the senses of the traveler across travel writing discourses by foregrounding the varied ways in which physical landscapes appeal to the senses (of smell, touch and sound) of the traveller. Advocating a phenomenological theory of travel, Segalen argues that the body is the channel or the mediator between the interior and the exterior worlds. A journey often leads to places beyond the threshold of one's familial environment and the traveller is quick to encounter "difference" or "otherness", what he terms "alterity" (Segalen, 1929, p.14-15). This

(C) AesthetixMS 2020. This Open Access article is published under a Creative Commons Attribution Non-Commercial 4.o International License (http://creativecommons.org/licenses/by-nc/4.o/), which permits non-commercial re-use, distribution, and reproduction in any medium, provided the original work is properly cited. For citation use the DOI. For commercial re-use, please contact editor@rupkatha.com. 
underscores the complex negotiations, an interplay between different identities. Travel writing has been instrumental in describing different types of travel -- forced and chosen, tourism and exile, appropriation and return, movements of ideas and cultures, to list a few. The thrust of this paper shall be to explore Assamese travel writings and the ways in which they envision a poetics of difference by not only describing physical movements across different geographical spaces but also movements of ideas, forced movements, tourism etc. I particularly emphasize on the term 'difference' to show how travel narratives from Assam attempt to portray their material conditions while describing their empathetic engagements with non-native cultures in the travel accounts.

Travel writing in Assam has had a curious history which initially began as a series of European encounters to the region often infantilizing and objectifying the natives of place to the documentations by the Assamese gentry whose accounts abounded in descriptive sketches and picturesque descriptions of the sights and scenes. Then there have been accounts of the traveller who, having been deprived of the facilities and requisite mobility and capital to travel, used his imaginative and creative faculties to account for the descriptions of people and places to the kind of traveller who consciously and with rigour, describes the self and the travelling body as the site of knowledge production, and the changes that had come about in his travel resulting from the encounter with different entangled subjectivities. Michael De Certeau opines that "Every story is a travel story" (Certeau, 1980, p.12). What seems to be apparent here is not merely the physical movements as a part of travel but also the various cognitive registers that the traveller or the travel writer takes stock of while penning down his story. Inderpal Grewal (1996) for instance, notes, travel writing has the propensity to unsettle certain assumptions about the "consolidation of stable unitary identities of nation, class, sexuality, or gender, and suggest forms of selfhood that evade such consolidations" (Grewal, 1996, p. 3). Travel writing from Assam is closely linked to the ideas of nationalism, identity, globalization, multiculturalism, insurgency, as is the case with travel writing from other parts of India. The travel writer wrestles with the ideas of the centre and the margin, border crossings, hybridity, location and displacement by espousing a poetics of difference. That said, the first section of this paper attempts to provide a brief introduction to postcolonial travel writing in general and Assam travel writings, in particular and the conceptualization of the idea of travelling identities, bodies and poetics of difference, the second section seeks to provide a chronological development of travel literature as a distinct genre in Assamese literature. The third section attempts to analyze select travel narratives as underscoring the importance of the self as the site of agency and knowledge and how they advocate for a poetics of difference.

\section{Assamese Travel Writing and the Poetics of Difference}

In their book on postcolonial travel writing, Justin D Edwards and Rune Graulund write that the purpose of postcolonial travel writing is not merely about "writing back." As the editors elaborate in their Introduction:

The word 'postcolonial' imparts potential for dislocation, disjuncture and even rupture when it is combined with a genre -- travel writing -- that has been critiqued within postcolonial circles. Thus, we seek to shake the reader's complacency through the unmapping of mapped critical areas and decentering dominant theatrical territories. (Edwards and Graulund, 2010, p. 6) 
The preoccupation of the postcolonial travel writer was to not only offer a critique of the misrepresentation of the natives in the Western counterpart but to envision the poetics and politics of difference in their writings. Assamese travel writing for the longest time has been trying to shake off the veneer of offering descriptive accounts to critically engaging with ideas surrounding identity politics and challenging the hegemony of mainland India and the west in terms of biased representations of the people of the Northeast in their travel accounts. MacCannell (1976) envisions the idea of tourism as grappling with the 'authentic other'-- an 'imagined' authenticity, exoticized the Orientalist other. Elsewhere, Graburn (1983) has argued that tourism is a practice of liminality --an escape from the here-and-now, which in the Deleuzean terms could be read as "deterritorialization" and "reterritorialization" (Graburn, 1983, pp.15-16). Postcolonial travel writing scholars from the Northeast in general, and of Assam in particular, have had a great deal of allegiance to pay to Edward Said's Orientalism in the sense that, in reaction to the depictions of the "oriental other" in the popular depictions of the Orient in Western travel narratives, there emerged a counter "travel" narrative from the Northeast much later. By then, the images of the East or the Orient had come to form a "regularizing collectivity"ii (Edward Said's term) in the travel archives of the West. His book came to establish how 'travel' came to be the central element in the epistemological construction of the other. Said's thesis attempted to show how 'travel' was inextricably intertwined to ideas of colonial expansionism throughout human civilization. In the earliest written travel accounts, which appeared in the early decades of the seventeenth and eighteenth centuries, European travellers paid willful obeisance to the discourses of the Empire.

I use the term poetics of difference by which I mean travel narratives emerging from this part of the sub-continent engage with the idea of travel as not merely a physical journey but a psychological journey, in which the travel writer negotiates with his "alterity" while encountering the other -- things that are not easily comprehensible to him and that are outside the purview of his understanding. These accounts are also careful descriptions and observations of the everyday material realities of the people that are meshed with politics of the region. The varied journeys undertaken by the traveller towards the latter decades of the twentieth century essentially foreground a "narratorial self" in which the travel writer not only lays bare his subjective experiences through the prism of his perceptions, but also the various dialogic and intersubjective processes at work by which the travel writer attempts to understand the world navigating various geographical spaces. I attempt to make an analysis of the travel narratives that have emerged from Assam, keeping in mind the idea that "the postcolonial" has always been a contested terrain which provides multiple avenues for disruption, disjuncture and rupture. Assamese travel writings seek to negotiate with multiple alterities and subject positions by questioning the notion of "real" and "authentic" travel.

\subsection{A Historical Trajectory of Assam [borderland] travel narratives}

Narratives of journeys, border crossings and encounters with alien cultures have existed since days of yore. The idea of border and margin is crucial to understanding Assamese travel narratives, as the people writing from the region have to constantly negotiate with divergent cultures and subjectivities. In his expansive travel account Borderlands: Travels Along India's Boundaries (2017), Pradeep Damodaran writes about forgotten frontiers which are located at the periphery in which the government at the centre is too dismissive to care about. Describing his travels across Tamil Nadu, Lakshadweep, Bihar, Sikkim, West Bengal, Arunachal Pradesh, 
Manipur and Andaman and Nicobar Islands describing the history, geography and traditions of these border towns, the author is cautious to point out the pitfalls in infrastructure and healthcare facilities. Written in a language easily accessible, he tactfully describes the daily struggles, the people on the frontiers have to encounter on a daily basis. His representations of the physical and human dynamics of the regions also seem to give a lie to various spatial and discursive accounts of the borderland regions which have existed in narratives about the Orient, in the archives of the West and also the government at the centre. That said, borderlands are subjected to twice marginalization- by the virtue of being the producer of the idea of "exoticity" which seem to be paramount in accounts by Westerners, and also the apathy of the central government towards the people at the fringes, undermining the existence of the Northeast, and by extension, the subjectivities of the persons.

Travel narratives which have emerged from the Northeast can be classified under the category of borderland travel narratives. These accounts not only seem to be conscious about their self-projections in their accounts, but their narratives attempt to offer a counter discourse to the narratives of the West and the regional exoticization of the Northeast as the "other" in travel accounts "about" the Northeast that have been emerging from within the Indian sub-continent. These accounts tend to revel in their "difference". Like Amitav Ghosh's In An Antique Land(1992), travel writings from Assam seek to offer an "alternate" narrative, if not subvert and dismantle the colonial and mainstream India travel accounts of the Northeast altogether. Travel writing from and about the Northeast gained ascendancy with people writing about the region as a popular tourist destination owing to its "exoticity." James Clifford in his "Notes on Theory and Travel" divided the traveller into distinct categories-- pilgrims, merchants, navigators, cartographers, explorers, tourists, travelers etc. by referring to Paul Fussell's contention who had drawn a distinction between explorers, travellers and tourists (Clifford, 1997, 84).

One of the earliest known accounts of a foreigner travelling to the North East was the accounts of the European traveller Ralph Fitch (1585) who had travelled to the region for purposes related to trade and commerce. His travels found mention in Richard Hakluyt's The Principal Navigations. This was followed by accounts of the Dutch traveller Frans van der Heiden (1675)- a Dutch East India company sailor who accompanied the expedition of Mir Jumla to Assam being privy to the war, history, trade relations and topography of the region. The experiences of the French traveller (Baptist missionary) Jean Baptiste Chevalier, whose purpose of visiting the region was directed by a proselytizing intent, has been documented by Caroline Dutta Baruah, only very recently. (Baruah, 2008). Thomas Welsh, William Griffith, John Butler were some of the European travellers who had travelled to Assam during the later decades of the eighteenth and early decades of the nineteenth century. These colonial travel writers in their depiction of the natives, could, at best, "exoticize" and "infantilize" them.(Welsh, 1769; Griffith ,1847; Butler, 1855). In doing so, they were catering to the imperialist project of depicting the "other" as the noble savage who were hankering to be civilized by the West. These travel accounts fall within the category of Paul Fussel's explorers, tourists and travellers who were out on an epistemological navigation and travel which sought to unearth the knowledge of the other and present them to the West. As Homi Bhabha stated in his The Location of Culture, "colonial discourse produced the colonized as a fixed reality which is at once an "other" and yet entirely knowable and visible. It resembles a form of narrative whereby "the productivity and circulation of subjects and signs are bound in a reformed and recognizable totality" (Bhabha, 1994, p. 72). Travel writings such as these, for the longest time, existed in the corpus of the Assamese travel writings as "the versions" of travel implying that European travels were the only modes of travel. They seem to pay a disservice to 
non-Europeanized modes of travel and the knowledge gained thereof. Issues along these lines is what Tabish Khair's Other Routes: 1500 Years of European and Asian Travel Writing (2005) addresses at length showing how Europeanized modes of travel went to the extent of erasing the differences of the other.

Though there has been a copious amount of travel writings in Assamese, not many have garnered attention. Much of it falls within the ambit of "travel histories" and "travel reports." The first detailed account of travel literature was purported by Hemanta Kumar Sarma. In his account, he charts a trajectory of the evolution of travel writing from the early decades of the twentieth century to the latter decades of the twentieth century. His accounts can be found in Hamprotik Asamiya Sahityar Norup, Norekha (2010) (Assamese Literature- New Horizons, New Directions). Later on, his accounts which charted the historical trajectory of the literary field, was published in Asamiya Sahityar Drishtipat(2013) (New Avenues in Assamese Literature). The focus of these accounts is not as much on human relationships as it is on the "encounters" with different cultures. A latter account of travel writings cataloguing the journeys undertaken in between the mid decades to the penultimate decades of the twentieth century till the 2000 san be found in Prasanna Kumar Nath's "Bhraman Kahini: Asamiya" (2005) (Travel Writings: Assamese). The travel accounts of Hemanta Kumar Sarma and Prasanna Kumar Nath archive the travel narrative of the encounters with non-native cultures of India and the West vis-à-vis the social, cultural, historical and political backdrop of Assam. The importance of writing from within the boundaries of the region(al) space is significant, for it entails a thorough dissection of the indigenous material that is oven overlooked in travel narratives that have emerged about the region that is being written about by these travel writers. It also enabled them to probe the multiple and often layered histories of the region and also the fault lines that are apparent within the region, thereby creating a distinct mode of expression -- which is a marriage of the personal, political and also catering to the requirements of the generic form. They offer illustrative and illuminating instances of the way in which certain networks and systems of knowledge production can be undermined by travel writing by the natives.

The germ of the first travel writing by a native in Assam lay in the early decades of the nineteenth century with Gunabhiram Boruah's Saumar Bhraman(1890) which catalogues his six months trip to Saumarpeeth. Soon after, Ananda Chandra Agarwala wrote a travelogue called Brahmajatrir Diary (1895) which recounted his travels to Burma. Their exposure to social connections and capital facilitated their mobility to distant lands beyond their territorial limits. Hemanta Kumar Bharali writes about the inaccessibility of travelling by people owing to financial and bodily constraints. These travel accounts which were often written by a privileged lot, having the requisite capital to travel, incorporated in their narrative, a nostalgia and yearning for the roots, apart from being descriptive sketches of the place visited. Bharali stresses the imaginative and creative potentials of the travel writer in creating a narrative and "emplotting" a story from the multitudinous vignettes of experience. (Asomkosh p. 343). Travelogues or travel stories which cursorily mentioned Assam included Ram Mishra's Brindaban Charit and Tripura Buranji which appeared as early as 1740 and 1724. The thematic strands of these travel accounts can be summarized as: historical descriptions, political accounts, economic relations, social relations, educational scenarios and vivid natural descriptions -- a thorough geographical scrutiny. Jan Brom, in his essay "Defining Travel: On the Travel Book, Travel Writing and Terminology"(2004) argues that travel writing is not a genre but a collective whose main theme is travel. Rejecting Theroux's idea of travel as merely seeing and recording events, Brom stresses on the "fictiveness" 
in the travel accounts, in recounting the conversations during the course of the travel. Quoting Mary Louise Pratt further, Brom writes that editors and travel writers make significant changes in their manuscript embellishing it with numerous ostentatious phrases and descriptions. (Brom, 2004, p.13-16).

These ornamented descriptions also have a yearning for "home", which could perhaps be on account of the fact that Jnandabhiram Barua and Birinchi Kumar Barua's narratives were written down during their stay abroad. These post-independence travel accounts, however, were the first recorded travel narratives which have been preserved till date. Jnanadabhiram Barua's travel "memoir"- Bilator Sithi (Letters from Foreign Country) was published in 1948. Around the same time, Dr. Birinchi Kumar Barua's travelogue Switzerland Bhraman (1948) (Journey to Switzerland) and Professor Baruar Sithi(1968)(Professor Barua's Letters) were also published. All these three travel accounts abound in variegated descriptions of the sights of nature, elaborate descriptions of differences between their culture and cultures of the West, and almost a "narcissistic engagement with the mobility of the self" and also a "nostalgic yearning for the roots" (return?). They had come up with their travel narratives at a time when not many people had travelled to distant places owing to numerous constraints.

Hem Barua's Sagar Dekhisa (1955) (Have You Seen the Sea?) has been one of the finest testaments of coastal travelogue. Ranga Karabir Phul (1959) (The Red Oleander), Mekong Nai Dekhilo (1967) (I have not seen the River Mekong) soon appeared after the poet-critic's visit to various continents. These travel memoirs are characterized by a style-- simple yet complex in the intricate details of the natural scenes that the poet so convincingly describes. Amalendu Guha's Soviet Deshot Abhimukhi (1966) (A Peep into the land of the Soviets) similarly contains details about his visit to the regions of the then Soviet Union, detailing the precarious plight of their people caught in the ebb of the Communist regime. Syed Abdul Malik's Majat Mathu Himalayas (1969) (Himalaya only in Between) and Naba Kanta Barua's Deshe Deshe Mor Desha (1972) (My Country in Different Countries), Gautam Barua's Nana Desh, Nana Rang (1975) (Varied Countries, Varied Colours) is full of picturesque descriptions of the vignettes of the country and the city, and not a reproduction of the prejudices of the colonizers. Often the persona of the traveller, awed by the picturesque details of the landscape, would wander with an empathetic gaze to learn about the various practices and habitual customs of the land. These narratives (that of Hem Barua, Amalendu Guha, Syed Abdul Malik, NabaKanta Barua and Gautam Barua) which were a part of the descriptions of "places" resulting "from the physical experiences [and mobility] of travel produces in spatial, psychological and aesthetic terms" which Supriya Chaudhuri rightly argues in her essay on "Indian Travel Writing".(2019, p. 161.)

With the advent of independence, people started travelling to various regions within the subcontinent for reasons pertaining to education, trade and commerce resulting in travel accounts which documented the cultural differences between their native and non-native cultures of the sub-continent. Thus the travel writings of this period seem to echo what Johannes Fabian calls "allochronic discourse" in which he notes a sharp break between the journey of the other and journey of the self, so that a spatial journey was also a temporal progress towards the advanced Western civilization (Fabian, 2014, p.ix-xiii). Part of this is attributable to the writers' encounter with colonial education which had brought about a change in their perception of the west. The host of travel writings within this category included Lakhinandan Borah's Seemar Paridhi Vangi (1959) (Breaking the Circumference of the Boundary), Nagen Saikia's Americat Dah Din(1955) (Ten Days in America) and Mahendranath Borah's Smritipatat America(1966) (Reminiscing America), narratives which also foreground the imaginative and creative potential of the travel 
writings in the writer's knack for description and elucidation. Rathindranath Goswami's Mahasamudrarpaar (1990) (Along the Shores of the Gigantic Sea), Pradipta Borgohain's Lincolnor Dexor Atithi (1999) (Guest to the Land of Lincoln), Karabi Deka Hazarika's Neela Sagararu Sonali Dex(1999) (Of Blue Sea and the Golden Nation) seem to depict the beauty of language in which they do not merely revel in describing, but have the critical eye for precision and analysis. Govinda Prasad Sarmah's Daffodil Ful Dekhisa (2001) (Have You Seen the Daffodil), Surendra Mohan Das's Tolostoyor Dekhat (1996) (In the Land of Tolstoy), Uma Baruah's Sien Noir Dhou(1990) (Waves of Sien Lake) and Lalit Boruah's Europeor Batot (1999) (Along the Roads of Europe) again outline the importance of memory and narrative in the context of travel. They seem to attach importance on the significance of selective remembering and reconstruction from the multitudes of experience. Nirupama Borgohain's Sarag Narakar Majedi (1999) (Treading between Heaven and Hell), Hemanga Biswas's China Sai Ahilu (1993) (My Visit to China) and Akou Chin Sai Ahilu (2002) (Of My Second Visit to China), Birendra Kumar Bhattacharya's Chinat ki Dekhilu(1996) (What I Saw in China), Nirmal Prabha Bordoloi's Cherry Fulardekh Japan (1991) (In the Land of the Cherry Blossoms), Jayanti Chutia's Haiku aru Samurair Dekhat (1994) (In the Land of the Haiku and Samurai), and Raghav Chandra Deka's Penguinor Desh Kumeroo (1998) (Kumeroo, the Land of Penguins) are testaments of the visual and the descriptive with an intellectual rigour and they are outside the importance of the self as the site of knowledge production.

Soon after, a section of travel narratives appeared with the sheer prowess in reporting the details. These writers are seen to exhibit a penchant for story-telling, their finesse in "emplotting" situating them at the grey area between fact and fiction. Though these kinds of journalistic accounts have been apparent in a large number of travel writings that seem to have come out of Assam in particular, and the Northeast in general, they remind the readers of a Bruce Chatwin or Jonathan Raban. Subrata Boruah's Himtirtha Bodrinath (1995) (Travels to Snowcapped Badrinath), Premlata Dutta's Alakanandar Para Sagar Tiroloy (2003) (From the banks of Alakananda to the shores of the sea), Srinath Dev Goswami's Panchadham Panchatirtha(2001) (Quintet Travels to the Five Dhams), Harinarayan Dutta Boruah's Bharat Bhraman (200o) (India Travels), Anu Baruah's Delhir Dukhariya Chabi (1999)(Broken Portrait of Delhi), Dipika Bhattacharya's Prayagor Pare Pare(2004) (Along the Banks of the Prayag) etc. However, during this phase, travel narratives documenting the everyday lives of people within the Northeast also came into prominence such as Lakheswar Sarmah's Misimi Paharar Ronsinga (2005)(War bells of the Mishmi Hills), Premlata Borah's Seujia Paharar Maje Maje (2008) (In the Midst of the Green Hills) and Lila Gogoi's Simantar Mati aru Manuah (2010) (Land and People of the Borderlands). Some travel writings which had turned its focus on the self as the site of knowledge and discovery include Utpal Kumar Kakaty's Distant Destinations (2015), Tapan Kumar Sharma's Manar Deshot (2015) (In the Land of Manas) and Karnaphulir Parat (2015) (Along the banks of Karnaphuli). What seems to be paramount in this whole trajectory of literary works is that we notice a definite shift in travel narratives which had engaged from paying willful allegiance to the West, to reveling in "ornamentation", to turning the gaze "inwards" to the self as the site of knowledge.

\subsection{Bodies as Sites of Knowledge and the Poetics of Difference in Assamese Travel Writings}

This section shall purport to look into how certain travel narratives, from each period of the historical trajectory described in the previous section, focus on the importance of the travelling 
body and identity as sites of knowledge and how they offer a poetics of difference to travel writings that have emerged from the West or the Indian sub-continent, both of which seek to other the subjectivities of people of the Northeast, as I mentioned earlier. The Assamese travellers have been instrumental in describing the various cross-cultural contacts across various temporal and spatial locations. Colonel Sir James Johnston's account of Thomas Welsh's travels to Assam in 1877 and John Butler's account of his travels to Assam in 1794 depicted the local inhabitants as indifferent and apathetic owing to their opium addiction. Butler writes:

There is no article of commerce sought after with such intense avidity in Assam as kanee or opium; and its baneful effects can only be appreciated by those who witness the degeneracy of the people. It is consumed by all classes, high and low, rich and poor, old and young, men, women and even children; and its consumption is only limited by the purse or means of the opium eater. (Butler, 1794, 25)

Similar to Butler's accounts, Welsh's 1794 report indicated the consumption of opium by the natives, which also indicated their "desire" to establish trade relations with them. He writes, though opium was consumed by the natives, they were "yet unacquainted with the manufacture of merchantable opium, which might be procured in considerable quantity." (Welsh, 1794, 117). Gunabhiram Barua's Saumar Bhraman(1890) is characterized by a simplicity and clarity which is often unparalled in the corpus of Assamese travel writings which had gained prominence in the succeeding decades. He blatantly refers to the various "soundscapes" that appealed to him, underscoring the physicality of his travelling experience. Hem Barua's Sagar Dekhisa (1955) underscores the importance of the moving body as the site of knowledge production in instances when he describes the magnitude of the sea he encounters upon his first visit. The vastness of and the boundless sea exercises a visceral effect on the mind of the travelling poet-critic. The sound of the waves, the smell of the sands and the conch shell could be read in terms of Victor Segalen's idea of the "aesthetics of diversity". The sounds heard by the traveller also bear testimony to the fact of having navigated through different spatial and temporal locations. In a similar vein, Nagen Saikia's Americat Dah Din (1955) and Surendra Mohan Das's Tolostoyor Deshot (1996) attempt to offer a picture of their encounters with foreign cultures and their mobile bodies question certain questions and discourses pertaining to identities, nationalism and race. Of particular importance is Tolostoyor Deshot (1996), in which Surendra Mohan Das goes on to describe different locations of Russia- the "sounds" of Latvia, the "scent" of the fisherman villages in Riga etc attesting to the corporeality of the encounter. Lila Gogoi's Simantar Mati aru Manuh (2010) and Utpal Kumar Kakati's Distant Destinations (2015), seem to underscore the importance of the cultural negotiations and of the fluidity of identities when they reiterate on the motif of the "airport". The airport has often been envisioned as "global crossroads", where "bodies in transit" come into contact with a variety of people resulting in a cross-cultural mix. Their dexterity in "emplotting" and convincingly holding on to the multiple threads that run across their narrative, make for a convincing storytelling. As Arjun Appadurai in his book Modernity at Large (1996) argues "what is the nature of the locality as a lived experience in a globalized, deterritorialized world?" (Appadurai, 1996, p. 52). His contention may often be at loggerheads with the kind of travel writings that have emerged from the Northeast, since he seems to have problematized the very idea of "locality" in a globalized world. However, travel writings which have been discussed above and the ones such as Ananda Chandra Agarwala's Brahmajatrir Diary (1895), or Anu Baruah's Delhir Dukhariya Chabi (1999) or Jayanti Chutia's Haiku aru Samurair Dekh (1994) uphold the importance of what Edward Bruner calls the "model of entangled agencies" that their positions as a local cosmopolitan in which identities and selves are constructed and reconstructed and is an 
ever ongoing process of matching the local with the global, a process entailing mutual transformation. (Bruner, 2005, p. 10). These travel narrators have infused their narratives with larger questions surrounding identity politics, belongingness and the urgency of defining one's home in relation to the social and political dynamics of the country.

\section{Conclusion}

In conclusion, it can be surmised that travel writings of Assam can be rich repositories of information, unapologetic renditions of the material realities of the people vis-à-vis their relation to non-native cultures. The earliest exploration of travel narratives in Assam were mostly by European travellers who had the gaze of the European visiting the land of the "other" where they seem to have encountered their inverted mirror images. These accounts seemed to be in keeping with Foucault's contention that knowledge is [never] innocent but profoundly connected with operations of power. (Foucault, 1980, p. 43). These accounts created a rich dichotomy between the East and the West, also between mainland and borderland India within the nation. Though the initial phases of Assamese travel writing indicated that "access" to travel was not in the hands of everyone, thus bringing into its ambit, the notion of class privileges and economic prosperity which found reflection in their writings. The portrait of the Assamese gentleman traveling to lands beyond their homelands, have in them, a penchant for intricate details and the splendour, the difference of the lands vis-à-vis their customs and practices, seemed to be the dominant motif. The latter decades of the twentieth century and early twenty-first century witnessed the transformation of the self from being a passive, reticent observer to an active agent who did not tend to other the addressee but had the empathetic gaze of the traveller and it became accessible to people across classes and economic status. However, the streak of description and drawing a sharp line of demarcation between the visited country and the homeland seemed to prevail. It seemed to be pervasive with the vignettes, anecdotes of the everyday lives of land visited in relation to the politics and insurgent politics that are the part of the region they hail from. What they seek to do is not merely present a narrative which effortlessly attempt to 'visibilize' themselves, but manages to stir the conscience of the readers who tend to have half-baked knowledge of a region torn asunder as much as by the violence emanating from the region as by the racial, political and epistemic violence meted out to the inhabitants of the region.

\section{Notes}

\footnotetext{
i In his Escapade (1929), Victor Segalen uses the term "aesthetics of diversity" referring to the appeal of the varying locations/locales to the senses of the traveler.

ii Edward Said mentions the term "regularizing collectivity" in his book The World, the Text and the Critic by which he refers to how certain discourses get solidified as knowledge.
}

\section{References}

Appadurai, A. (1996). Modernity at Large: Cultural Dimensions of Globalization. Minnesota: University of Minnesota Press.

Bhabha, H. K. (1994). The Location of Culture. London: Routledge. 
Bharali, H. K. (2007). Asomkosh. Dibrugarh: Banalata.

Borgohain, H. (Ed.) (1993).Asamiya Sahityar Buranji ( $6^{\text {th }}$ Series), Guwahati: Anandaram Baruah Bhasha-Kala Sanskriti Sangstha.

Borah, J. K. (2010). Sahityar Nana Dish. Dibrugarh: Banalata.

Borah, M. (Ed.) (2007) Bhasha Sahityar Barnali. Jorhat: Sanskriti Prakashan.

Brom, J. (2004). Defining Travel: On the Travel Book, Travel Writing and Terminology in Perspectives on Travel Writing (Glen Hooper). London: Penguin.

Bruner, E. M. (2005). Cultures on Tour: Ethnographies of Travel. Chicago: University of Chicago Press.

Butler, J. (1794). Travels and Adventures in the Province of Assam: During a Residence of Fourteen Years (1855). Montana: Kessinger.

Chaudhuri, S. (2019). Indian Travel Narrative in The Cambridge History of Travel Writing. (Eds. Nandini Das and Tim Youngs). London: Cambridge. pp. 159-174.

Clifford, J. (1997). Routes: Travel and Translation in the Late Twentieth Century. New York: Harvard University Press.

Damodaran, P. (2017). Borderlands: Travels along India's Boundaries. New Delhi: Hachette.

De Certeau, M. (1980). The Practice of Everyday Life. California: University of California Press.

Dutta Baruah. C. (2008). Adventures of Jean-Baptiste Chevalier in Eastern India (1752-1765). Guwahati: Lawyers Book Stall.

Edwards, J. D \& R. Graulund. (2010). Postcolonial Travel Writing: Critical Explorations. UK: Palgrave Macmillan.

Fabian, J. (2014). Time and the Other: How Anthropology Makes its Object. New York: Columbia University Press.

Foucault, M. (1980). Power/Knowledge: Selected Interviews and Other Writings 1972-1977. London: Vintage.

Ghosh, A. (1992). In an Antique Land. London: Penguin.

Goswami, J. (2002). Asomiya Sahitya rChamu Buranji. Guwahati: Asom Book.

Graburn, N. H. H. (1983). The Anthropology of Tourism. Annals of Tourism Research, 10 (1), 1983. pp. 9-33.

Grewal, I. (1996). Home and Harem: Nation, Gender, Empire and the Cultures of Travel. London: Duke University Press.

Johnston, Col. Sir J. (1877). Captain Welsh's Expedition to Assam in 1792, 1793 and 1794. Calcutta: The Foreign Department Press.

Kakati, U. K. (2015). Distant Destinations. Guwahati: Aalipat.

Khair, T. (2005). Other Routes: 1500 Years of African and Asian Travel Writing. London: Signal Books.

MacCannell, D. (1976). The Tourist: A New Theory of the Leisure Class. New York: Schocken Books.

Nath, P. K. (2005). Bhraman Kahini: Asamiya. Guwahati: Bani Mandir

Sharma, T. K. (2015). Karnaphulir Parat. Guwahati: Students' Store.

Segalen, V. (1929) Escapade (trans. from the French by Segalen) Paris: Gallimard.

Sarma, H. K. (2013). Asamiya Sahityar Drishtipat. Guwahati: Bina Library.

Sarma, H. K. (2010). Hamprotik Asamiyar Sahityar Norup ,Norekha. Guwahati: Bina Library.

Sharma, T. K. (2015). Manar Deshot. Guwahati: Students' Store.

Said, E. (1978). Orientalism: The Western Conceptions of the Orient. New York: Penguin.

Said, E. (1983). The World, The Text and the Critic. Massachusetts: Harvard University Press.

Thompson, C. (2011). Travel Writing: The New Critical Idiom. London: Routledge. 